\author{
Sidey Myoo \\ (i) https://orcid.org/0000-0001-6163-4742 \\ Department of Aesthetics, Institute of Philosophy \\ Jagiellonian University \\ michal.ostrowicki@uj.edu.pl
}

\title{
COGNITIVE VALUES IN NEW MEDIA ART
}

\begin{abstract}
The theme of this paper refers to the research approach which may be framed as the narrative and explanatory aspects of art, but with specific stress on New Media Art. Author's objective is to show that artists perceive phenomena which in social perspective are frequently neglected despite their importance and which could be surely abandoned in public discourse unless they become the objects of artworks. A few examples may support this claim such as widespread web mediation, determination of artists based on common use of new technologies, and also possible surveillance of individuals, mediation of content as well as emerging authority based on massive web manipulations. Therefore, I would like to stress that art has become an indispensable and original source of knowledge on modern times, and with the use of original form, it may be persuasive and intervene for social change and/or warn against e.g. injustice, incline to reflect, inspire and educate the public. These themes have been analyzed with reference to several artworks which raise specific and meaningful questions.
\end{abstract}

Keywords: contemporary art, new technology, artistic message, context, art cognition, social education

Artists frequently reflect on social issues, making critical interventions part of their artworks and artistic approach. To a certain extent, art may be conceived as an activity predestined to comment on reality in the way that is unlikely to be substituted by encyclopaedias, policy makers, business or conventional education practices. Thus, the role of art may be understood as a universal language that competes with other forms of human communication through the use of metaphors, symbols, stimulating reflection and inspiring the audience to focus on new techniques and content. Clearly, over time, art has undergone dramatic changes in terms of its form, but one can hardly be deny that it employed specific forms of codes in order to encourage people to 
reflect on the idealistic content of artworks more effectively than other forms of communication. ${ }^{1}$ The skills of observation, experience of the changing world, visionary interpretations, creativity, and also critical but constructive approach to social issues allowed artists to recognize new trends and use their symptoms in their creative arts, discussed in this paper, such as the development of new media and the consequences of such phenomena. ${ }^{2}$ Since the 1970s, a number of trends in the New Media Art have risen, such as, for instance, web art, VR art, gps art and monitoring art, AI art and bioart, where the public could see artworks commenting on social phenomena arising from technological development, which from time to time played a role of a "manual" for the recipients, allowing them to better understand and cope with them. ${ }^{3}$ Contemporary works may sometimes be used as a game and/or form of a play, which at first glance seem not to trigger any consequences. However, it frequently happens that contact with an artwork may result in the opening the recipient to understand essential aspects of the reality which in turn may be referred to a similar situation in his/her life.

One of the first artists initiating the New Media Art who significantly contributed to the idea behind the concept of the electronic environment (Virtual Reality) and the significance of the being online is Myron Krueger. ${ }^{4}$ His interactive artworks emerged in the beginning of the 1970s and nowadays are the milestones in the development of virtual reality art and co-emerging phenomena, such as telemacity and immersion. ${ }^{5}$ Krueger's reflections originated from the intuition that it is possible to understand a technical image as the interactive and functional space which are the type of reality where man could lead their activities. Even though those claims have not been substantiated by

1 You may name the nature of art which was seen for centuries from ancient times, e.g. in Greek tragedy and the concept of katharsis, and also to tell visual stories in Renaissance (frescoes from The Sistine Chapel and/or Garden of Earthly Delight), or point to more literal meaning of art understood as a means of communication in the 20th Century, where conceptual values expressed were more important than aesthetical.

P. Vanouse, Counter Laboratories, Inverted Suspects and Signs, [in:] P. Vanouse, Fingerprints..., Argobooks, Germany, 2011, pp. 45-64: http://www.paulvanouse.com/Vanouse-Fingerpintsessay.pdf and M. Ożóg, Perspektywy dialogu nauki i sztuki w pracach Art Orienté Objet i Paula Vanouse'a, [in:] P. Celiński, ed., Mindware. Technologie dialogu, Lublin 2012, pp. 97-114. R. W. Kluszczyński, Strategies of interactive art, „Journal of Aesthetic \& Culture”, Vol. 2 (2010): http://www.aestheticsandculture.net/index.php/jac/article/view/5525

M. Krueger, Artificial Reality II, Addison-Wesley Publishing Company Inc., 1991, pp. 38-39.

5 Telematicity is linked with sensual experience whose source is not in the physical world, but the virtual reality (R. Ascott, Telematic Embrace Visionary Theories of Art, Technology, and Consciousness, Edward A Shanken (ed.), Berkeley, University of California Press, 2003), and, in turn, immersion is the state of entering the virtual reality leading to permanent state of being there, sometimes at the cost of activity in the physical world (O. Grau, Virtual Art. From Illusion to Immersion, The MIT Press, Cambridge MA, London 2013). 
a thorough ontological analysis which was caused by the use of the concept of artificial reality which restricted the ontic significance of the virtual reality as a domain of being, Krueger's intellectual propositions clearly define him as the first visionary artist and researcher who demonstrated that the virtual reality needs to be associated with the reality based on the grounds of technology.

One of the major artworks by Myron Krueger is Videoplace (1975). ${ }^{6}$ The artist used the technology which resembles modern Kinect which controls movement in space, but the first gear used the camera to achieve that. The mentioned artwork uses a multisection and diversified installation in the physical area. The audience were situated in the interactive space in several similar installations in physical reality which were part of this major project. Owing to the connection of their interactive images, each viewer could watch the visual content on the connected image which was displayed on each separate place (fragments of the installation), while remaining in various parts of the physical area. Due to the interactive properties of the installation, the audience could show gestures to each participant which allowed Krueger to observe and define the concept of telemacity mentioned earlier, that is the feeling of a physical touch which did not originate in physical contact, but using Web mediated devices. This work contains ideas owing to which it could be possible to analyze widespread existing phenomena such as interactivity and/or immersion or telemacity mentioned earlier. ${ }^{7}$ This artwork anticipated the electronic reality which is in common use nowadays. Thus, we might say that in this sense Krueger's work is a good example of the use of and attempt to define what is commonly known, but in those days was only a visionary project and thus needed new definitions.

Several years after Videoplace Masaki Fujihata ${ }^{8}$ completed his Beyond Pages (1995), which could be interpreted as another significant work that

6 F. Franco, J. Gardiner, N. Lambert, (red.), CAT 2010: Ideas before their time: Connecting the Past and Present in Computer Art, Birkbeck University of London, Swinton, British Computer Society 2010, p. 80, 98-99.

7 An interesting example may be the artwork by Karen Lancel, Hermen Maat - Kissing Data (2014), where artists shows a remotely controlled kiss, using EEG gear, which is able to record brain-waves as an electromagnetic wave, and then experienced and repeated by other persons. Questions whether or not such a kiss is real may arise; also the possibility to record it in a database and sharing with other persons: „Can I kiss you online? How does your kiss feel in E.E.G. data? Can we transfer a kiss and it's intimacy online? Can we measure a kiss and what kissers feel together? Do we want to save our private kisses in a transparent database - to be used by others? In E.E.G. KISS the artists investigate how a kiss can be translated into bio-feedback data. They deconstruct the kiss, to reconstruct a new synesthetic kissing ritual. In a Global Kiss-In, through feeling, seeing, hearing, touching all participants together share a kiss.": https://www.lancelmaat.nl/work/e.e.g-kiss/

8 S. Wilson, Information Arts. Intersection of Art, Science, and Technology, Massachusetts Institute of Technology, Cambridge, Massachusetts, London 2002, p. 768 and also S. Myoo, 
makes it possible to interpret the virtual reality as one more sphere of valuable reality. It is an interactive installation composed of a projection of a book screened from above on the surface of the table. This projection contains nine themes (book pages), including, for example, an animated image ion of a disappearing apple in such a way that it becomes invisible each touch of an electronic pen as if it was eaten, and another image of a stone which is moved by the electronic pointer. At that time when the artwork was created you could define it as a futurologist work as the phenomenon observed in it, mainly mentioned earlier, i.e. telemacity and the issue of the web personality, became the object of more detailed study only much later. ${ }^{9}$ Fujihata's intuition was correct when he scrutinised the relations between those two elements of the reality, namely the physical and the electronic (virtual) ones and depicted as inter-twinned and only then emerging the importance of the electronic being. The form of the installation was also symbolic as it was only an empty room, which did not contain the features for using it for residential purposes, except for serving only as a means for access to the web. Thus, such a room despite being a place where the most important emotions take place, has no separate meaning. Being only a physical place the room serves nothing more than a connection to the web and staying there. The room in the Beyond Pages has become only an empty physical space from which mental world and emotions went away to the electronic world.

Other works where interesting cognitive values related to the physical and electronic realities could be found are installations by Jeffrey Shaw, Golden Calf (1994) and some artworks by Don Ritter, but I am specifically interested in his interactive installation Fit (1993). However, the work by Jeffrey Shaw seems more intriguing. His interactive installation was made of an empty pedestal and display which any user may take. If you would like to look at the pedestal in the physical reality, you could see nothing on it. However, using the display directed towards the pedestal, you could watch an image of the golden calf. This interactive installation reveals the value of participation, namely the need of using the technology and being connected. Today those values have become so indispensable as we use technology in every day issues to deal in professional and private matters. In the case of Golden Calf the recipient is unable to interact with the pedestal without the display, and the message about the golden calf is not transmitted to them. Everyday connection with technological devices may

Masaki Fujihata - Beyond Pages, P. Zawojski (ed.), Klasyczne dzieła sztuki nowych mediów [Classical work of New Media Art], Instytucja Kultury Katowice - Miasto Ogrodów, Katowice 2015, pp. 90-97.

9 D. Baron, A Better Pencil. Readers, Writers, and the Digital Revolution, Oxford University Press 2009. 
become a chronic need and lead many people to constant monitoring of events appearing on the web and, consequently, become their lifestyle. New issues appear in modern times when individuals deprived of technology or with limited access to it may seriously suffer from the negative consequences of it which often may lead to technological exclusion.

Another work worth mentioning is Fit, which, like Golden Calf, is an interesting installation which is one of Ritter's installation referring to the theme of the relation between the physicality and electronic and showing the impact of media on the human who is dominated, manipulated and/or exposed to persuasion. Those three issues are different, but they share one feature in common: they may influence behaviour of man. In Fit, the artist showed the subjection of human psychomotorics to the created image, which, despite its unnatural changes, creates determined behaviour of the viewer. This installation is made of a display and an interactive space with movement sensor. You could see a fitness coach on the display performin more and more rapid movements which with the lapse of every few seconds. The viewer staying outside and before the display in the interactive space makes efforts to follow the coach's movement patterns making similar gestures more and more quickly and coming to the stage where this exercise is too difficult as it is exceeding the physical capacity. The show unveils the patterns when the viewers after several dozen seconds trying to follow "the fitness coach image" become exhausted and leave tired the interactive space. Though it is clear that man is unable to make so speedy and absurd exercises, their psycho-motoric movements is subjected to the electronic image, that is the image in the electronic medium has dominated man. It seems obvious that in particular the proscenic media such as TV or radio still are the main if not the exclusive source of information and as such the influence on the public behaviours, values and opinions, and therefore spreading unverified information, and then social manipulation. This work also showed adaptive features of man with reference to the image and interface which could be named as the phenomenon of entering any electronic medium into relation with the human. In fact, Fit is an education work where you could see the power of the media and the absurdity of the human behaviours. You could see some irony in it which is at the same time terrifying as it reveals how the human is able to subject to the media and change its nature.

A good example of a web artwork that comprises aesthetic values related to family and maternity is Contraception (2005) by Ewa Szczyrek. She created a virtual world resembling a 3D computer game, but the artist aimed to engage the recipient by simulating their feelings with reference to maternity. Joint custody of the parents over their virtual child is part of mutual relations of the participants in the project Contraception. Their shared links created partnership in the virtual world. Despite the fact that their child was a bot, that part- 
nership and human relations became complex and emotionally engaging with the lapse of time. This work showed the theme of responsible maternity where, firstly, the care over the child could replace other issues including those existing in the physical world, and secondly, reveal common phenomenon of emerging relationships in the web - showing them in the passing of time (the length and frequency of time) and emotional commitment where they may be observed as oscillating between the playing with other man's feelings and searching for a partner for life. The length and frequency of time spent online may be crucial for preserving the relationship, which in turn may cause the contacts become the most significant component of human day-to-day life. Good feelings created in the web contain real and expected experiences which lead to emerging of satisfaction and fulfilment among the web users. In my opinion, uninterrupted participation in web life and redirecting intentional activities to the web in search for pleasure for which there is no alternative in the physical world are among the most important features of modern life. Consequently, web activities attract attention and a variety of expectations from man which may lead to the situation where their emotional commitment may finally split from the relations in the physical world. ${ }^{10}$

Regarding Post-Internet artwork, where you could see interactions between the physicality and the virtuality the following two are of significance. The first one is Image Objects (2011) by Artie Vierkant. It is a hybrid installation which draws on interactivity in its web component where the artist focuses on two parallel constituting two timelines based on processes. The installation used a sculpture in the physical space, and owing to the camera its image was visible and transformed in the web. The physical form was fixed and it culminated in the creation of an exhibit which was not supposed to be changed in any manner. The same object when appeared in the electronic form reveals its changeable potential which has neither fixed not finite form. Possible interpretations are related to the aspects of its limited physicality and, in turn the reference to the electronic being as susceptible for easy changes and transformations. This work triggered a discourse between the changeable physicality as well transformed on the web and the unchangeable and completely finite in the physical world as it could be seen in the sculpture's "death" in the exposition space and at the same time its transformed life in the web.

Another Post-Internet artwork where you could see interesting cognitive values is An ordinary building (2006) by Eva and Franco Mattes. The idea behind it was to show a determining web medium in relation to the physicality. This work presented information in the web about a usual building in Viterbo.

10 N. S. Baron, Always On. Language in an Online and Mobile World, Oxford University Press 2008, pp. 8, 222. 
In the physical space this house was labelled with the text that its history was insignificant nor any widely acclaimed person lived there. Therefore, this information was also disseminated in the web and the building became known and visited in huge numbers by visitors. This artwork showed that just anything, not necessarily an object with features of traditional aesthetics and culture nature may attract viewers' attention. There is not much sense to see a common building, however, the media showcase and to certain extent stigmatisation in the web changed a worthless object, which gained in importance as a source of joint social experience which appeared the most significant factor in this phenomenon.

The work by Paolo Cirio - Loophole for All (2013) was well-received at Ars Electronica in 2014. This artwork aims to charge the global taxation system where global companies are able to avoid paying taxes, and on the other hand an ordinary citizen is forced to pay them. This is a highly developed installation with its one part in the physical world and the other in the electronic world.${ }^{11}$ It is common knowledge that global corporations are not necessarily bound with a concrete state taxation system, so they may transfer their financial means and obligations anywhere. Ordinary person is not allowed to pay taxes where he wishes, therefore, he is not a part of the globalisation system as there is not such a law in the entire world. This system reveals its injustice when we look at the aforesaid different situation between the two. Paolo Cirio's idea was to allow to buy a fictional certificate of ownership a company on his website, which was registered in a tax haven, worth at least 99 cents. Anybody who wishes to use such a fictitious deed and start doing business and pay taxes may try to avoid taxation in a given country and instead register their company in a tax haven. It's evident that this artwork to certain extent relies on fraud, however, its aim was to reveal in a dramatic manner that global corporations in view of the binding law are allowed to profit from such privileges which does not apply to the ordinary person. The cognitive value of this work may be seen in intervening in the situation which is obviously and frequently not seen and understood by common taxpayers. Information about taxation is not classified, but it is not widespread too. Such situation is under change, if it could be shown by the artist when they reach wide audience as artwork may send a strong and convincing message. It is in particular the case if the work published on the web arouses interest on global and international scale.

Finally, I would like to refer to two artworks belonging to the bioart. The first one is a hybrid and global project by Joaquin Fargas Big Brain Project

11 H. Leopoldseder, Ch. Schöpf, G. Stocker, (red.), International Compendium - Prix Ars Electronica 2014. Cyber Arts 2014, Hatje Cantz, Ostfildern 2014, pp. 58-61: http://archive.aec. at/media/assets/65cb27ad06f07ce322f27941ebe52813.pdf 
(2012). It is futurologist in nature, but it contains fascinating technological compound, because it uses the tissue of nervous system of a rat, which may contain mental-like processes. Also, it is a bit mysterious, for despite the measurements it is not visible what kinds of processes take place in it, e.g. they are similar to thinking or sensation. Its hybrid components attract the attention of viewers because it draws on the use of biological tissues and computers. ${ }^{12}$ Owing to the web computers are able to process the biological impulses which are dispersed and installed in labs all over the world. Fargas's work discusses the question of bionics, that means the link between the biological and nonbiological substance. The aesthetic and cognitive values lie in the importance of the hybrid composition which may join processing the biological and nonbiological substances and in this way overcome the boundaries of information processing between the intelligent machine and biological matter. This intuition seems interesting because some research in cognitivism show that mental processes, that means behaviours intelligent, intentional and/or conscious exist in different matter and not only in the biological one. It may be possible that by creation of joint biological and hardware interface communication process could take place in both of them. But it is not the matter which is important, but the very phenomena existing in it. ${ }^{13}$ The theme of intelligence in the broader context of hybridisation is of high importance as the future dimension may result in not predicted way from the posthumanistic perspective. Fargas draws on the components of the processed based on the two types of matter and the communication processes between the two which currently becomes interesting, but nevertheless it arouses anxiety among many researchers. ${ }^{14}$

The other interesting work is Gilberto Esparza's Plantas autofotosintéticas (2013) which was awarded with Golden Nica at Ars Electronica Festival in 2015 in the category of hybrid art. ${ }^{15}$ This work raises ecological questions. The installation with central position of a transparent ball where there is a small biosystem including animals, plants and some water. Next to the ball there are some transparent containers similar to columns which are connected with the ball by cables. Some additional pipes are linked with the "columns"

12 K. Hayles, Writing Machines, The MIT Press, Cambridge MA, London 2001, p. 39.

13 D. Chalmers, The Conscious Mind. In Search of a Fundamental Theory, Oxford University Press. 1996, p. 279.

14 K. Warwick, Cyborg morals, cyborg values, cyborg ethics, [in:] "Ethics and Information Technology", Kluwer Academic Publishers, 5/2003, pp. 131-137: http://www.ai.rug. nl/ sympocie/2006/articles/artikel_warwick.pdf

15 H. Leopoldseder, Ch. Schöpf, G. Stocker, (red.), International Compendium - Prix Ars Electronica 2015. Cyber Arts 2015, Hatje Cantz, Ostfildern 2015, pp. 60-63. 
providing contaminated water serving the bacteria as a source of nourishment. At the sides there are anaerobic bacteria whose metabolic system purifies the water and creates power. Every once in a while, in the central ball there is a flash of light emerging from this bio-process which, in turn, allows to activate the photosynthesis process and growth of plants and animals in the ball. This artwork contains interesting cognitive values emerging from the collecting of energy coming from biological purification and life process. This technology is not new, but the artist's idea was to disseminate it in e.g. cities' sanitation systems and support the local sanitations works. The work shows the biological technology which could be introduced to the cities in day-to-day practice and, perhaps, minimise the waste in the places where there is shortage of pure water. This work has also social and intervention dimensions, because it promotes ecological actions and reveals methods how to achieve its goals.

$* * *$

Art may be persuasive, and convincing, it may arouse reflections and support education. But, neglecting its aesthetic values like beauty, it gains more and different potential to reveal to man which is important to them due to the importance of the content and experience. Works of art possessing aforediscussed cognitive values may be intellectually and emotionally interesting for the viewer and reveal wide knowledge transgressing pure aesthetics of the work of art. The process of reception of it may lead the recipient to understand some aspects of the reality, and, consequently, trigger social change. This aspect of art was known from the ancient times in the form e.g. katharsis, and its impact is still important, but nowadays art may reach wider numbers of viewers than in the past.

\section{BIBLIOGRAPHY:}

Ascott Roy (2003) Telematic Embrace Visionary Theories of Art, Technology, and Consciousness, Edward A Shanken (ed.), Berkeley: University of California Press.

Baron Dennis (2009) A Better Pencil. Readers, Writers, and the Digital Revolution, Oxford University Press.

Baron S. Naomi (2008) Always On. Language in an Online and Mobile World, Oxford University Press.

Chalmers David (1996) The Conscious Mind. In Search of a Fundamental Theory, Oxford University Press. 
Grau Oliver (2013) Virtual Art. From Illusion to Immersion, Cambridge MA, London: The MIT Press.

Hayles Katherine (2001) Writing Machines, The MIT Press, Cambridge MA, London.

Kluszczyński Ryszard W. (2010) Strategies of interactive art, „Journal of Aesthetic \& Culture”, Vol. 2: https://www.tandfonline.com/doi/full/10.3402/jac.v2i0.5525

Krueger Myron (1991) Artificial Reality II, Addison-Wesley Publishing Company Inc.

Lambert Nick, Gardiner Jeremy, Franco Francesca, eds., (2010) CAT 2010: Ideas before their time: Connecting the Past and Present in Computer Art, British Computer Society, Birkbeck University of London.

Lancel Karen, Maat Hermen - Kissing Data (2014): https://www.lancelmaat.nl/work/e.e.g-kiss/

Leopoldseder Hannes, Schöpf Christine, Stocker Gerfried, eds., (2014), International Compendium - Prix Ars Electronica 2014. Cyber Arts 2014, Hatje Cantz, Ostfildern, pp. 58-61:

http://archive.aec.at/media/assets/65cb27ad06f07ce322f27941ebe52813.pdf

Leopoldseder Hannes, Schöpf Christine, Stocker Gerfried, eds., (2015) International Compendium - Prix Ars Electronica 2015. Cyber Arts 2015, Hatje Cantz, Ostfildern 2015, pp. 60-63: http://archive.aec.at/media/assets/ff1a5e038397076ddc383c6aff9356bc.pdf

Myoo Sidey (2015) Masaki Fujihata - Beyond Pages, [in:]. P. Zawojski, ed., Klasyczne dzieła sztuki nowych mediów [Classical work of New Media Art], Instytucja Kultury Katowice - Miasto Ogrodów, Katowice, pp. 90-97.

Ożóg Maciej (2012) Perspektywy dialogu nauki i sztuki w pracach Art Orienté Objet i Paula Vanouse'a [The Perspective of dialogue and art in work Art Orienté Objet and Paula Vanouses], [in:] P. Celiński, ed., Mindware. Technologie dialogu, Lublin, pp. 97-114.

Vanouse Paul (2011) Counter Laboratories, Inverted Suspects and Signs, [in:] P. Vanouse, ed., Fingerprints..., Argobooks, Germany.

Warwick Kevin (2003) Cyborg morals, cyborg values, cyborg ethics, "Ethics and Information Technology”, Kluwer Academic Publishers, vol. 5, pp. 131-137:

http://www.ai.rug.nl/ sympocie/2006/articles/artikel_warwick.pdf

Wilson Stephen (2001) Information Arts. Intersection of Art, Science, and Technology, Massachusetts Institute of Technology, Cambridge, Massachusetts, London.

\section{WARTOŚCI POZNAWCZE W SZTUCE NOWYCH MEDIÓW (streszczenie)}

Tematyka artykułu nawiązuje do narracyjnego i eksplikatywnego znaczenia sztuki, mając na uwadze głównie Sztukę Nowych Mediów. Celem jest pokazanie, że artystki/artyści wyraźniej dostrzegają nierzadko słabo widoczne w percepcji społecznej, choć ważne przejawy rzeczywisto- 
ści, o których mówią poprzez sztukę, a które to treści najpewniej nie zostałyby zaprezentowane szerszej publiczności, gdyby nie stały się tematem prac artystycznych. Wiąże się to np. z takimi fenomenami, jak powszechne zapośredniczenie do sieci, determinacja wynikająca z codziennego użycia technologii, możliwa inwigilacja człowieka, mediatyzacja wszelkich treści, także wynikajaca z rozwoju sieci władza lub manipulacja. Sztuka zatem staje się niezastąpionym i oryginalnym źródłem wiedzy o współczesnych czasach, a gdy operuje oryginalną formą może być perswazyjna i przekonująca, może interweniować lub przestrzegać, skłaniać do refleksji, inspirować lub edukować. Tematykę tę przedstawiono na przykładach kilku prac artystycznych, zawierających specyficzne, znaczące treści.

Słowa kluczowe: sztuka współczesna, technologia, przekaz, kontekst, poznanie, edukacja

Sidey Myoo is an academic pseudonym inspired by an online handle, adopted by prof. dr hab. Michał Ostrowicki in 2007, in Second Life. Sidey Myoo is a philosopher; he works in the Department of Institute of Philosophy of Jagiellonian University and in the Department of Theory of Media Art of Faculty of Intermedia in Fine Arts in Kraków. $\mathrm{He}$ is interested in aesthetics, treated as a theory of art, mainly in relation to contemporary art, including electronic art. Since 2003 he analyzes the philosophy of the web, and phenomena such as immersion, interactivity, telepresence, telemacity, hybridization, immateriality, identity, artificial intelligence. He stresses the importance of development of technology, which creating or transforming whole human world. In 2006 he used the notion of virtual realis (later: electronic realis), which has become a basis for ontoelectronics, which is the ontology focused on the analysis of electronic reality, treated as a sphere of being. It is assumed here that the electronic environment is a kind of alternate reality to which man increasingly moves its activity, gaining network identity. Sidey Myoo is the author of articles, monographs and edited works on philosophy and arts. He has participated in national and international scientific events.

In 2007 he founded the Academia Electronica (www.academia-electronica.net) - noninstitutionalized part of Jagiellonian University, acting on the model of university in the electronic environment in Second Life, where are carried out official, academic courses and conference's presentations.

michal.ostrowicki@uj.edu.pl

www.sideymyoo.art.pl

www.academia-electronica.net 